\title{
Building fisheries institutions through collective action in Norway
}

\author{
Svein Jentoft ${ }^{1} \cdot$ Bjørn-Petter Finstad ${ }^{1}$ \\ Received: 31 May 2017 / Accepted: 12 December 2017 / Published online: 16 May 2018 \\ (C) The Author(s) 2018
}

\begin{abstract}
Institutions, and the collective action that created them and which they enable, can play an important role in poverty eradication. In Norway, the Raw Fish Act passed in 1938 in the aftermath of the international financial crisis that hit the fishing industry hard, and the fishers' cooperative sales-organizations that it authorized testify to this. Most of all, they helped to empower fishers in their economic transactions throughout the value chain. Since the RFA's enactment, it has undergone reform that has somewhat changed the mandate of the sales-organizations, but the basic principles and functions remain. Although the historical context and institutional designs of the Raw Fish Act and the cooperative sales-organizations that it mandated, are unique, together they addressed a problem that small-scale fishers are experiencing in other parts of the world - one of poverty, marginalization and exploitation. The Raw Fish Act and the system of mandated, cooperative sales-organizations radically altered this predicament and turned the table in fishers' favor. The question, therefore, is what lessons do the Norwegian example offer that might be emulated elsewhere?
\end{abstract}

Keywords Small-scale fisheries $\cdot$ Collective action $\cdot$ Empowerment $\cdot$ Norway $\cdot$ Raw fish act

\section{Introduction}

By the turn of the nineteenth century Norway was among the poorest European nations. Only Greece and Portugal had a lower income level than Norway (Cappelen and Røed Larsen 2005). During the first two decades of the nineteenth century, however, a process of economic and industrial modernisation took place, spurred on also by the First World War. For the coastal economy, the war meant an increased demand for Norwegian fish products by the main parties to the War, Great Britain and Germany, resulting in a significant price rise as a result. In the beginning of the 1920s the cycles turned again. The situation worsened due to the financial meltdown on Wall Street in 1928, hitting the export industries hard including that of fish products, the country's most important export industry. As $90 \%$ of Norway's fish products were exported, fishing communities felt the impact heavily (Christensen and Hallenstvedt 1990; Bull 1979).

Svein Jentoft

svein.jentoft@uit.no

1 The Norwegian College of Fishery Science, UiT The Arctic University of Norway, Tromsø, Norway
Although fish resources were abundant, easily available and open access, fishers still had problems earning a decent income - even when export markets improved. Their poverty was exacerbated by lack of bargaining power; buyers easily exploited them by transferring their market losses to the fishers who, as the weaker party, had to accept the terms offered to them. When prices dropped, which could happen in the course of a day, fishers had to work even harder and bring more fish ashore to compensate for the loss. Ironically, this further depressed prices. The situation reached a point where fishers, with their backs to the wall, finally responded. They organized collectively to break free of bondage (Hallenstvedt 1982: Grytås 2013a).

The government supported the fisher initiative in several ways. Most importantly, the Raw Fish Act (RFA) was passed by Parliament in 1938. The Act granted the fishers' cooperative sales-organizations the exclusive right to decide a fixed minimum level of the raw fish price. The Norwegian Fishermen's Sales-organization (NFSO) established the same year as the passing of the RFA, together with a number of other similar organizations throughout the country, has come to play a crucial role in Norwegian fisheries and society. On cannot understand the social and economic dynamics of the fisheries industry and its governance without a thorough analysis of the Raw Fish Act and the sales-organizations. These 
institutions helped empower the fishing population by prioritizing their needs, enabling them to exit a discriminatory bargaining situation, and overcome the hardships that the international financial crisis had brought upon them. This legal and organizational reform helped to bring the fishing population of poverty, which in parts of the country, especially in the most fisheries dependent northern region, was extreme. For a decade prior to the reform, raw-fish cod prices had been way below what they were before that period, whereas the cost of living had increased (Christensen and Hallenstvedt 1990). Child mortality in the 1920s and -30 s were at a level more extreme that in most developing countries today. In Finnmark, the northernmost county, 112 per 1000 children died within one year of birth (Rønning Balsvik and Drake 1994). In comparison, in 2015, 83 per thousand children in South-Saharan Africa died (thechildeshttp://data.worldbank.org/indicator/ SH.DYN.MORT).

In this paper we tell the story about how the RFA came into being; who initiated its drafting and why. In order to understand the significance of this law we start by discussing some key issues regarding cooperative organizations and collective action as they appear in small-scale fisheries globally. If organizations are a solution to poverty, marginalization and disempowerment, what are the hurdles to their realization? Cooperatives like the sales-organizations in Norwegian fisheries do not emerge spontaneously in a social and political vacuum. Their origin and sustenance require some form of collective action, either by way of a grassroots or external initiative, namely from within civil society or government supported, or perhaps preferably through concerted action involving both. Organizing fishers is not always an easy challenge for reasons that may have to do with their need for independence, lack of time and organizational skills (Hallenstvedt 1982).

How was this challenge overcome in the case of Norwegian fisheries? Who saw the need for legal and institutional reform? Norway's fishing industry looks very different today in comparison to when the Raw Fish Act was passed and the NFSO established more than 75 years ago. The Act and NFSO's survival has depended on their ability to stay relevant to the changing circumstances of the industry by adapting accordingly (Hersoug et al., 2015). What their future holds, therefore, depends on them being able to stay relevant.

We argue that although institutional designs must be fishery and country specific, the RFA and the cooperative salesorganization should offer inspiration for similar institutional reforms in other parts of the world. Norway is not a poor country today, and neither are fishers. But when the RFA saw the light of day, they were. The RFA resulted from a class struggle, and was a bold move of the Parliament to empower fishers and to release them from the bonds with the more dominant buyers. These issues are valid beyond Norway. Despite the fact that the Norwegian context is unique in many ways and that its particular history must be taken into account, the study describes a solution to a problem that exist elsewhere in the world of small-scale fisheries.

\section{Organization and collective action}

The theory underpinning fisheries resource use and management is essentially expressed as a Prisoner's Dilemma game. In this game, participants cannot avoid what Sartre (2006) called "counterfinality"; when they act in their individual interest, they underperform as a group. Individual and collective rationality collides. People could accomplish more for themselves and for each other if they agree to put their own private ambitions aside and work together for their common interest. However, in the case of collective goods (i.e. those goods that once they are provided cannot be reserved for anyone in particular) are concerned, it is always more profitable for individuals to free ride, i.e. take advantage of being able to use the good without contributing to its realization. Therefore, there will be an undersupply of collective goods, unless someone is willing to shoulder the burden, which in the absence of incentives would have to be an external agent, like the state.

This problem is at the heat of the Prisoner's Dilemma game and the Tragedy of the Commons, the parable famously discussed by Garrett Hardin (1968) and later Ostrom (1990). In fisheries, this tragedy is overexploitation, ruin of the resource, and the destitution of the resource users. This outcome is inevitable because users do what is rational from their individual perspective. As Hardin observed (p. 1244), "Ruin is the destination towards which all men rush, each pursuing his own best interest in a society that believes in the freedom of the commons."

Mancur Olson (1971) employed the same model for organizational formation and performance. While highlighting the advantages of having organizations for the realization of a collective good, he recognised that such organizations also faced collective action problems and hence were subject to the Prisoner's Dilemma. This is a "second-order collective action problem", which needs to be resolved first, before one can effectively address the problem at first order, like sustaining the common resource (Holm 1995; Heckathorn 1989). For a member, an organization provides benefits but also involves sacrifices, such as the willingness to contribute and comply. Staying outside the organization or remaining passive within it does not exclude one from enjoying the goods that it provides, such as healthier resources or higher prices.

Notably, the participants in the Prisoner's Dilemma game do not communicate or cooperate; rather they make their decisions in isolation. In the real world, this is not necessarily the case. For instance, within small groups or local communities, people know each other, share history and identity. In such 
setting, people often make decisions together. They also have the means to sanction penalties for deviating behaviour like free riding. Here, counterfinality is, therefore, not inevitable; self-organization is possible unless there is "community failure"; internal conflict, normlessness - or "anomie" as Durkheim called it (McCay and Jentoft 1998).

Counterfinality is closely related to scale: The larger the group, the lesser the incentive for individuals to self-organize, and lesser the capacity for informal sanctioning as social relations are not intimate. People who do not know each other are more likely to mistrust each other and less inclined to communicate and cooperate. In large groups that are not committed to agreements, breaking rules will be considered as cheating, whereas, in small groups the same act will be considered as "betrayal". A common political ideology may make up for some of the deficit, as for example within the labour and cooperative movements, but it may still be insufficient to avoid free riding. Fisher-members may find it profitable to sell their catch outside their cooperative (Davis and Jentoft 1989). The RFA made such behaviour illegal.

These general considerations about organization and collective action inform the organizational creation and structure of Norwegian fisheries. They make it easier to understand some of the essential challenges that confront any collective action. However, we also need a full and detailed account of what actually happened. In other words, to get the full picture, a "thick description" of the contextual and causal mechanisms that were active at a given point of time would be required (Vayda 1996). We would need insight into the real events that propelled people into collective action. That description follows in subsequent sections. For now, it is sufficient to point out that the co-governance system of Norwegian fisheries emerged in a crisis situation in the thirties that called for reform. This reform took years and finally resulted in a nationwide, coherent governance structure that involved fishers in partnership with a proactive state that was willing to delegate important management functions to cooperative salesorganizations of fishers, one of them being NFSO. The free rider problem was solved by giving NFSO and other fishers' sales-organizations a monopoly status; selling fish outside these organizations was deemed illegal, and persecuted if detected. This could only happen due to the RFA and the general legitimacy that the law enjoyed amongst Norwegian fishers.

\section{The Raw Fish Act - A short history}

To tell the story about the Raw Fish Act, we start by giving a short historical account of the geographical, social, and economic structures of Norwegian fisheries with special emphasis on the northern region. In this part of Norway, due to the Arctic climate, the conditions for agriculture are rather poor, whereas fisheries resources are rich and available close to the coast. In the three northern counties, Nordland, Troms and Finnmark, the cod fisheries have always dominated. The seasonal Lofoten fishery of spawning cod that migrates from the Barents Sea has been the most important source of income.

These fisheries were always crucial for northern coastal settlements. The total population in Norway in 1900 was 2.2 million, of whom only $35 \%$ lived in densely populated areas (Statistics Norway, www.ssb.no). Fishing and smallholding or a combination of both - was still the main occupation for the majority of the adult population in the coastal regions despite the fact that the industrialisation process had already started. In 1900, 82,000 people and 19,000 inshore and midshore vessels, mostly powered by oars and sails, were involved in the cod fisheries in the north (NOS 1901). With very few exceptions, the Norwegian fisheries were a rural industry. Fishers lived in small villages in the fjords and along the coast, the household being the most important economic unit (Wadel 1980; Solhaug 1983). Coastal households fished partly for subsistence, partly for cash.

Although fishers owned their vessels and gears themselves, they were locked into relations of dependence with fish buyers, which kept buyers in power and fishers in poverty. Buyers could dictate the terms of the transaction. Often, there were only one fish buyer in the local community; hence existing buyers had monopsony status. Moreover, fishers had no option, given the non-availability of other sources of supply, but to purchase essential goods and services such as flour, salt, sugar, gears, bait, etc. from buyers. Buyers were also creditors and often land owners as well. It was in other words a classic situation of a complex dependency relations that is still typical for small-scale fishers in many parts of the world.

It was easy for the buyers to control and exploit the poor and often illiterate fishing population. One known method of deceiving the fishers was to miscount the number of fish while purchasing. The concept storhundra (big hundred) refers to the common practice among fish buyers to pay the fishers for a hundred fish when in reality they took more than that - like one hundred and twenty. The extra twenty were simply not counted.

Between 1900 and 1920, a technological revolution took place in the Norwegian coastal fisheries with the arrival of the combustion engine (Johansen 2014). This new technology spread rapidly, after some initial scepticism amongst fishers, and by the end of the 1920s most of the fleet was motorised. The successful installation of engines in small-scale boats stands in striking contrast to the non-adoption of steam trawler technology within Norwegian fisheries.

The outcome, therefore, of the modernisation process was a fisher-owned fleet consisting of thousands of small and medium-sized vessels. Better economic returns and public funded technological innovation were the main drivers of this change. Historians characterise the motorisation of the coastal 
fleet as the "industrial revolution" of the Norwegian fishery sector. A motorised fleet led to increased mobility and productivity. The vessels could now reach new, more distant, fishing grounds, and consequently became less dependent on the vagaries of the weather. Another result of mobility was increased competition among buyers and consequently less dependence of fishers on particular buyers. On the other hand, motorisation created more debt for fishers, and hence vulnerability.

Stagnation of the international economy after the First World War and the financial collapse on Wall Street hit the Norwegian fishery sector hard because of its dependence on export markets. All those involved in fisheries lost out significantly because of price collapses within the most important stock fish (dried fish) and salted fish markets. Fishers tended to have to carry the heaviest burden because losses were simply transferred to them. Moreover, there was a tendency towards protectionism in international fish trade with the introduction of customs and import quotas.

This was the case because several nations increased their own catching capability in order to become self-sufficient as opposed to buying fish from outside. German and British trawl fishing grew significantly in the 1920s and 1930s. Both countries started targeting the same Barents Sea cod. Trawl boats from both these countries often damaged the long-lines and nets set by Norwegian fishers which triggered a strong opposition against foreign trawlers (Christensen 1991; Hovland et al., 2014).

The situation worsened for the small-scale fishers of the northernmost counties when the Russian Revolution put an end to the traditional, so called Pomor trade (Niemi 1992; Finstad and Lajus 2012; Nielsen 2014). Russian ships, during spring, used to sail from the north-western region of Russia to the coast of northern Norway. The Russians brought rye, sugar, hemp rope, and other goods, which they bartered for fresh fish that was cured directly on board. This seasonal trade was very important because during summer the conditions for production of stock-fish were bad. The Pomor ships offered the fishing households an alternative trade channel to the local fish merchants. When this trade ceased, they lost one of their most important livelihood sources.

The crisis in the Norwegian post-WWI economy was not limited to the fishing communities. The country witnessed a high unemployment rate among industrial workers who when they lost their jobs often started to fish, as the fishery was open access and the entrance costs were low. Hiring open row-boats was possible for almost everyone; so too buying bait and a hand-line. In the early 1930 s, there were more than 30,000 people involved in the seasonal Lofoten fishery, which was a record high (Jentoft and Kristoffersen 1989; Hovland 2014).

Such a situation of an overpopulated fishery with simple catch technology is known as the "primitivisation process" in Norwegian fishery history (Bull 1991:160-168). The many newcomers caused falling raw fish prices that now had to be distributed to a larger number of people. Buyers and exporters were thus able to lower prices. Fishers often returned home from the Lofoten fishery at the end of the season poorer than when they arrived there.

Lower prices meant that fishers had to work longer hours and take more risks during bad weather to maintain the same income level. They simply had to catch more. However, increased fishing aggravated the crisis as more fish in the market further depressed prices. A better strategy in the long run to maintain income levels was collective organization. In 1926, fishers established the Norwegian Fishers' Association (NFA) (Hallenstvedt and Dynna 1976; Hallenstvedt 1982; Christensen and Hallenstvedt 2005). This was the first nationwide organization for professional fishers, almost three decades after Norwegian farmers and industrial workers had taken similar actions. The miserable economic situation of Norwegian fisheries was from the start the priority issue. Since then the organization has played an important role in representing Norwegian fishers in the policy process as a consultative partner with the government. Internal strife between small- and large scale fisher members led to a breakout and the establishment of the Norwegian Coastal Fishermen's Association in 1987 (Fig. 1).

Another early example of collective action was the formation in 1927 by herring fishers in western Norway of a salesorganization called Storsildlaget (Christensen and Hallenstvedt 1990:29-36). This organization attempted to create a fishers' cartel so as to control prices vis-à-vis buyers in this particular fishery. The organization received legal protection in 1930 with the passing of the Herring Act. The Act stated that sale of herring from fishers to processors was prohibited outside the mandated sales-organization and that the terms of sale were to be set by the same organization. This arrangement was to become the legislative and organizational benchmark for the fisheries sector as a whole including that of the cod fisheries.

The cod fishers of northern Norway bore the heaviest burden of the market crisis within fisheries. Prior to the Lofoten season in 1930, attempts were made by the government to reach a voluntary agreement with buyers for a fixed minimum price level "in first hand" (Christensen and Hallenstvedt 1990:38-42), but the effort failed. A turning point came in 1936, when the Parliament adopted an arrangement for a guaranteed minimum support price for fishers including state subsidies so as to cover any losses incurred (Christensen and Hallenstvedt 1990:55). The immediate reason for the government's intervention in fish sales was the closure of the stockfish export to Italy, one of the most important markets. A total breakdown in this market put pressure on the Norwegian authorities to act.

The arrangement was a breakthrough for fishers. For the first time, they could prepare for a season knowing what raw 
The Raw Fish Act

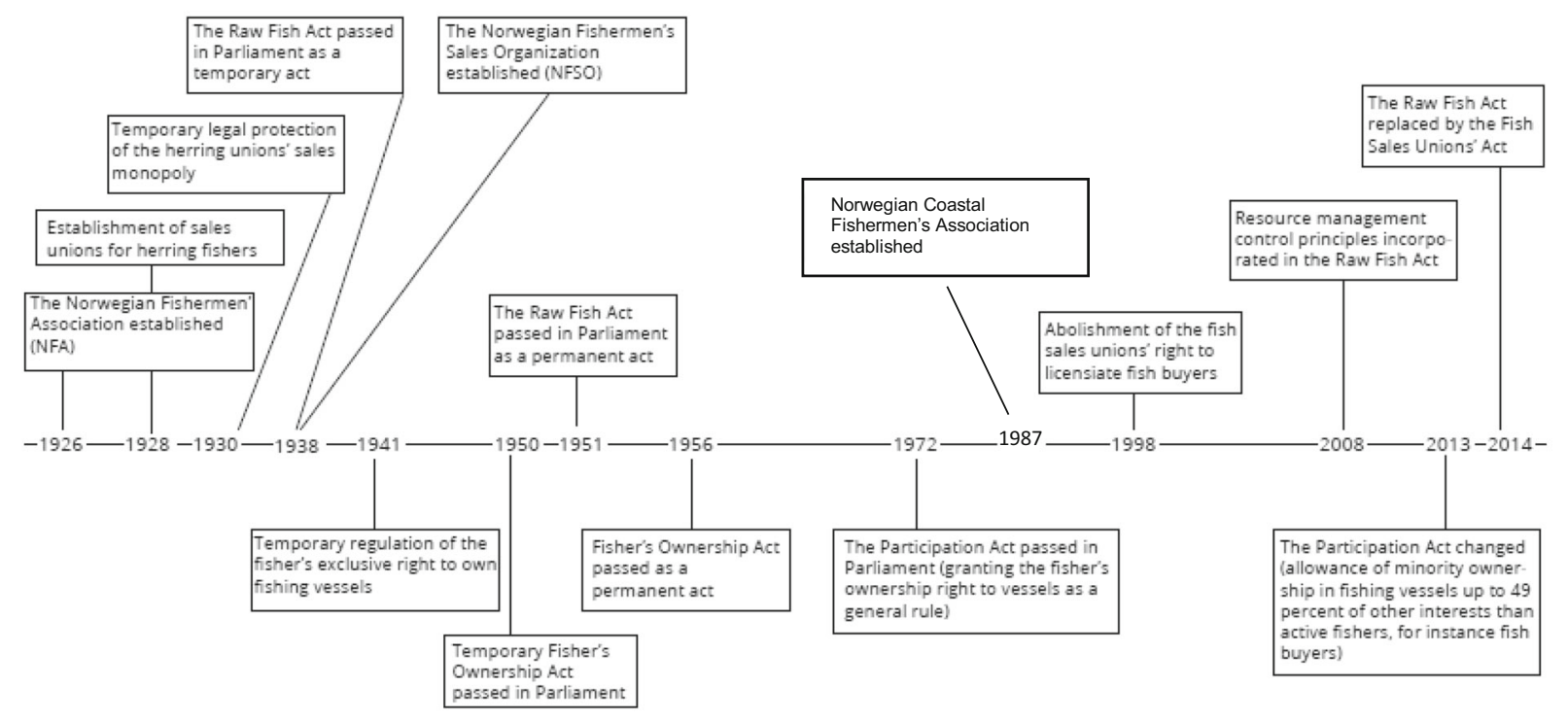

The Fisher's Ownership Act and Participation Act

Fig. 1 The legislation and organization history of fishing in Norway

fish prices would be. However, the fishers also knew very well that this was only a temporary measure dependent on Parliament's continued approval of subsidies. One weakness of the agreement was that it was limited to sales of cod for stock-fish and salt-/clip-fish production. In some fishing villages, export of iced fresh fish made a small but significant economic contribution to both fishers and buyers; there was however no government support for this. Other important species such as haddock, halibut, and coalfish, were also not part of the scheme.

In 1937, a fisher's strike broke out in the town Vardø in Finnmark County (Christensen and Hallenstvedt 1990:7076). The fishers claimed that the minimum support price system should be sanctioned by law. That a strike broke out here was no coincidence. Vardø was then one of the most important fishing towns in northern Norway, located strategically close to rich fishing grounds. The town housed a number of fish buyers and export firms and was the centre of an important spring seasonal fishery, based on cod (that fed on capelin). In addition to Vardø fishers, every year many visitors took part in this fishery. In the period 1935 to 1939 , the participation varied between 9000 and 21,000 (Finstad 1993:59). The strike made an impression on the central authorities. Consequently, the government accelerated its effort to find a solution to the fishers' poor economic situation.

Finally, in 1938, after many years of struggle to find a solution to the price issue, the Raw Fish Act was adopted (Hallenstvedt 1982; Christensen and Hallenstvedt 1990; Grytås 2013b; Hersoug et al., 2015). However, before the draft law was presented to the Parliament, the government required a referendum. All active fishers from the county of Sogn og Fjordane and north of it were asked whether or not they would approve of a mandated organization buying and selling all raw fish on their behalf (Christensen and Hallenstvedt 1990:87-88).

The response was overwhelming. About 22,000 fishers cast their vote, and between 91 and $96 \%$ of fishers in the four northernmost counties welcomed such an organization playing the role of seller as mandated by the RFA (Christensen and Hallenstvedt 1990:105). The legislator, i.e. the Parliament, had a solid mandate from the group that the law meant to serve. Simultaneously, with the completion of the formal legislative process, the NFSO was founded in November, 1938, by representatives from the regional departments of the NFA (Fig. 1). 
The RFA would never have seen the light of day without coordinated action by fishers and active support of the government. Counterfinality was avoided by concerted effort. From a broader perspective, however, the new act was in line with contemporary trends. The 1930s represented a farewell to orthodox economic market principles in many countries. First, Keynesian corporatism with elements of protectionism replaced liberal private capitalism in western economies. The state became a more active participant in the economy both through planning and direct intervention.

In Norway, the RFA turned the tables in the fishing industry as it shifted the bargaining power from the buyers to the fishers. No wonder, therefore, that buyers and exporters contested the law from the very beginning through condemnation and resistance. This, however, had no impact although opposition to the RFA is still very much alive. Notwithstanding opposition to the RFA, the law has undoubtedly had positive effects not only for fishers but also for other participants in the value chain, contributing to stable conditions for processors and exporters. No less important was the fact that the law was an incentive for exporters to become more proactive and efficient in the final market, which resulted in larger revenues for the entire industry and the country as a whole (Hallenstvedt 1982).

\section{The Raw Fish Act - Content and mandate}

The Norwegian Parliament made the 1938 Act permanent in December 1951, a delay caused by the WWII when Norway was under German occupation and the Norwegian cabinet resided in London. The Act has since then undergone some changes. This includes removing the provision that gives sales-organizations the authority to license buyers (Hersoug et al., 2015). The main principles, however, have survived until this day. Thus fishers' power in terms of their transactions with buyers has been maintained. Section 2 of the Act highlights the continued power of sales-organizations:

"The King may decide that the processing, sale or export of raw fish ... or products thereof shall be prohibited regardless of where the fish is caught if first-sale of the raw fish has not taken place through or with the approval of a fishermen's sales-organization whose statues have been approved by the Ministry concerned. Sale by an approved sales-organization is regarded as first-sale. Purchase of and settlement for raw fish fished on a share or percentage basis by owners of vessels, owners of gear or other co-partners is also regarded as first sale." (http:// extwprlegs1.fao.org/docs/pdf/nor13984E.pdf).

This principle gives a fisher sales-organization both a monopoly right and a clear mandate. By giving the sales- organization an exclusive right to trade raw marine fish, the Act makes it illegal for fishers to sell the catch outside the organization directly to a private buyer and for a buyer to purchase a catch from other than the sales-organization. Free riding is therefore banned.

The "freedom" that Garret Hardin talks about (see above) is ruled out. Without this legal provision, it is likely that the sales-organization would have disintegrated, as the parties would have opted out if opportune, a possibility that would have severely weakened the organization's ability to fulfil its role, i.e. to stabilise prices.

Furthermore, in section 3, the relationship between fishers, the sales-organization and the state is outlined:

"The Ministry concerned may under section 2 of this Act approve statutes for sales-organizations of fishermen when the fishermen or owners of vessels or gear can become members through direct membership, or when membership can be obtained through fishing boat crew, local sales-organization or through the fishermen's trade organization, and the sales-organization is formed with limited liability and with an indefinite number of fishermen" (http://extwprlegs1.fao.org/docs/pdf/ nor13984E.pdf).

The sales-organizations are owned by the fishers who automatically become members through their regional interest organizations (subsidiaries of the NFA) or directly as personal members. The former is by far most common. According to the law, only fishers or organizations of fishers can be members. Regardless of their membership status, and whether fishers are members at all, fishers still have to sell their fish through the sales-organization and on their terms.

Membership is limited to active fishers residing within the geographical district covered by the particular sales-organization. The governing board is elected amongst the fisher members at the annual meeting. The state has one delegate who participates at meetings and whose role it is to ensure that the sales-organizations are operating within the law, for instance to make sure that they are properly handling the delegated responsibilities regarding resource control. The NFSO's annual meeting can have up to fifty delegates, who for the most part represent various fisher organizations in the districts that NFSO covers.

"The herring sales-organization" (Noregs Sildesalgslag), which covers the whole country, specialises in pelagic fish (herring, mackerel and capelin). There are five other salesorganizations for all other wild fish species. In 1980, there were more than twice as many of them. However, since then some of these sales-organizations have merged both in the cod and the pelagic sector across the breadth of the country (see 
Table 1). In 2012, the NFSO processed 160,000 catches from 4430 vessels to 190 fishing industries, most of the latter being exporters. Table 1 reveals considerable differences in the scale of operations between sales-organizations in terms of sales volumes and staff numbers.

The law further states that the organization shall be entitled to levy a fee on the first-sale of all fish and products in order to cover the costs incurred by running the organization and administering sales operations, something that is subject to approval by the Ministry. Section 4 grants the sales-organization the authority to determine the terms of trade with the buyer, including the minimum price of the raw fish, which shall be fixed at a level that takes the price at the end market into consideration. If fishers were allowed to circumvent the sales-organization and sell directly to the buyer, this authority would be undermined. The sales-organizations and their processor counterpart organization hold negotiations over the first-hand prices several times a year. Should they not reach agreement, the sales-organization can unilaterally set the minimum price, which both the seller and buyer are obliged to respect. The two parties, however, are free to negotiate a higher price than that determined by the sales-organization, as when market suggests that the price can be higher. This also happens when there is competition for fish among processors and the market price is high. It is not uncommon that the actual raw fish price is considerably higher than the minimum price.

Section 5 also grants the sales-organization the authority "to impose a temporary prohibition on or order restrictions on fishing" when "required by market conditions, or to achieve an appropriate utilization of catches." This rule ensures that the sales-organization is delegated regulatory authority beyond simply the raw fish price issue to include concerns such as the extent of catches that can be sold to specific buyers outside a particular community or region when there is a glut in the local market and local capacity to buy were too low.

The organization can even mandate that fishing is periodically prohibited. Notably, this regulatory function is not for resource management but to avoid gluts in the raw fish sales and ensure that fishers can find a ready buyer nearby. It can of course be argued that this management function has an indirect effect on the harvest. According to the law, the salesorganization can also impose quotas on their members, even if they rarely do.

However, with the introduction of quota regimes in the 1990s, alongside resource management, sales-organizations have acquired a broader mandate to be part of fisheries management that previously was the preserve of the government (Hersoug 2006; Hersoug et al., 2015).

Sales-organizations have complete data needed to calculate harvest quotas since they are in charge of trading. The organizations register the time and place of all species caught and delivered, as well as their quantities. This management function is not something the sales-organizations took on themselves, but a function that they were ready and capable of doing. Hence, the government saw in the sales-organizations a means by which to ensure that both total and individual quotas are not exceeded.

This important function needed to be stated in the RFA. A new section was incorporated in the law. The provision to include this new function was stated as follows in the representation to Parliament (Ot.prp. no. 20, 2007-2008, p.134): "The sales-organizations have good knowledge of the challenges facing the government and fishers in the daily management of the fisheries resources and the control of the harvest."

This new management function helped create a comanagement system in which sales-organizations were given a broader mandate than the 1951 Raw Fish Act originally instituted. This change was first codified in the 2008 Ocean Resources Act and reiterated most recently in the revised Raw Fish Act of 2013, where paragraph 17 reads: "The government can instruct the sales-organizations to control the accuracy of the catch information even if the catch does not relate to the sales-right of the sales-organization (our translation, RFA 2013)." Further on, the ministry can describe and regulate how this task should be carried out.

\section{Discussion}

It is a general lesson to be noted (Holm 1995) that although the circumstances that exist at the time of the formation of an organization may have changed, the initial organizational

Table 1 Fishing Sales-Organizations in Norway (2013)

\begin{tabular}{|c|c|c|c|c|c|}
\hline Organizations & Established & Staff & Sales volume tonnes & Sales value $1000 \mathrm{NOK}$ & Web address \\
\hline Norwegian Herring Sales- Organizations & 1936 & 45 & 538,231 & $1,884,574$ & www.sildelaget.no/en \\
\hline Norwegian Fishers' Sales-Organization & 1938 & 60 & 711,574 & $5,744,341$ & http://www.rafisklaget.no/ \\
\hline Skagerakfish & 1947 & 5 & 8294 & 301,686 & http://www.skagerakfisk.no/ \\
\hline Rogaland Fishing Sales- Organization & 1946 & 2 & 5752 & 138,638 & http://www.rogfisk.no/ \\
\hline West-Norway's Fishing Sales- Organization & 1988 & 5 & 32,612 & 40,000 & http://www.vnf.no/ \\
\hline Sunnmøre and Romsdal Fishing Sales- Organizations & 1945 & 13 & 188,000 & $1,700,000$ & http://www.surofi.no \\
\hline
\end{tabular}


design often remains largely unaltered. To understand how the organization looks and operates today, one must therefore go back to the time of its establishment and how those who created it were thinking. This we have done in this paper. Given this observation, it is likely that over time a gap may appear between what the organization can offer and what the environment has reason to expect from it.

As this gap unfolds, the organization then becomes increasingly irrelevant and obsolete in spite of the fact it has been able to survive. The organization may have solved the problem it was created to solve and hence has outlived itself. Nonetheless the organization remains. In some instances, vested interests may be sufficient to ensure that the organization persists even if the original reason for its establishment is no longer valid. Organizations may persist but the legitimation for it changes, as when secondary effects become the primary ones or latent functions manifest themselves. The organization may survive because of resistance to change by powerful individuals who are reluctant to give up their power or see benefits distributed in different ways. Such a scenario often unfolds with collective goods.

However, organizations are not necessarily stuck in the past and unable to change, i.e. they may indeed adapt and modernise. What remains of the old organization may disappear over time, while a new, reinvented organization emerges. New goals and new functions may be added to the organization's original portfolio. The constellation of members may change, bringing in new ideas and concerns. Organizations are typically "political coalitions" where members and other stakeholders constantly negotiate ends and means (March 1962). Thus the ability of an organization to adapt and survive is a function of internal as well as external factors.

Organizations may remain unchallenged as long as its environment is stable, but become flexible and adaptive if the environment is volatile. Organizations with a collective mandate such as the Norwegian fishers' sales-organizations, will be challenged from the outside, by the public at large. Such organizations are not a private matter for members only. They are not totally autonomous but rather a part of the overall Norwegian fisheries governing system within which the state also has a crucial role. The legally mandated functions of the sales-organizations have therefore from time to time been scrutinised by the Fisheries Ministry and discussed by Parliament. The push to change sales-organizations has often been initiated from this level.

The number of fishers' sales-organization has been reduced over the years, but through a process of merging that has not created a vacuum. Organizations are now fewer but larger and more professional. They still cover the fishery sector in the whole country (see Fig. 2), and deal only with the fisheries capture industry. Without their monopsony/monopoly status, they would be vulnerable to exit and, hence, less effective, i.e. if fishers and processors would be allowed to operate outside the system. In this sense, they are different from the Producer Organizations within the fisheries industry of the European Union, where membership is voluntary.

It is nevertheless quite remarkable that the Raw Fish Act and the sales-organizational system have remained intact until this day, despite constant pressure from groups (processors and exporters) within the industry to undermine them because they saw their interests threatened (Hersoug et al., 2015). These attempts to undermine them have to some extent made it necessary for the sales-organizations to redefine their purpose and acquire new functions to defend their base. Fishers in Norway have been able to keep control of first hand raw fish sales because of sales-organizations.

In the age of neoliberalism and resource management, these organizations continue to play a crucial role in the overall governance system. This is explained by the general support the RFA enjoys in the fishing communities but also by the fact that the sales-organizations are powerful and wealthy organizations. Finally, there is a perception amongst fishers that the problem that these organizations were established to address in the first place may well resurface again if they are not there.

Norwegian fishers have become fewer and wealthier, and the industry is no longer the backbone of coastal communities that it used to be. Thus, the RFA has lost some of its social and political significance. It was instituted to deal with a situation where fishers were many and poor. Still, the law retains its symbolic force as the "constitution" of small-scale fisheries. It is taken as given and an "objective reality" of Norwegian fisheries (Berger and Luckmann 1967). One does not needlessly alter such laws without considerable political costs.

Although representatives of the processing industry have frequently voiced harsh criticism against the RFA and the monopoly power it grants the sales-organizations in setting the raw fish price, only one political party in Norway, the Progress Party ("Fremskrittspartiet"), has ever suggested that the Act should be abolished. This party is now in government with the Conservative party, and has the fisheries minister. However, in the official political platform, there is no such suggestion about the abolishment of the act.

Over the years, reforms have occurred, such as in 1998 the removing the authority of the sales-organizations to license buyers, but the law by and large remains intact, and thus continues to empower the primary producers, i.e. the fishers, in their transactions with buyers. This arrangement is quite unique in the world of small-scale fisheries and may provide a more 'global' lesson. If a fish buyer in Norway wants to increase his profit, he cannot do it on the back of another fisher; instead he would have to pursue it at the end-market with the retailer, exporter, or consumer. In that way the RFA was meant to vitalise the entire value chain and discourage "lazy monopolies" in the processing and export chain (Hallenstvedt 1982). In other words, the RFA was not just 
Fig. 2 Fishing sales organizations in Norway: Geographical Coverage

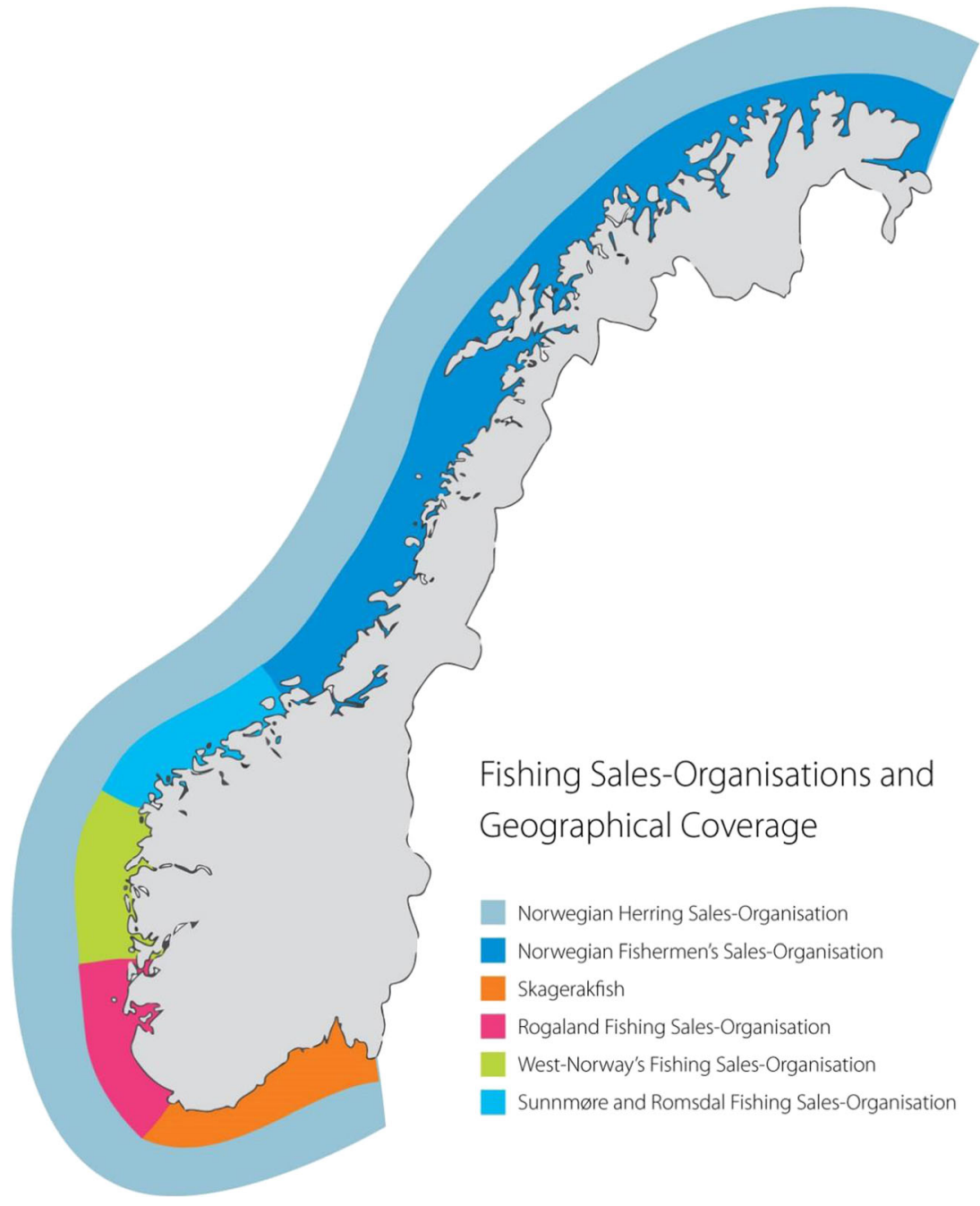

meant to serve fishers, but was intended to also improve the profitability of the fisheries industry and the Norwegian economy as a whole.

Notably, the Norwegian fisheries value distribution chain is a layered system of horizontal integration. The salesorganizations have a mandate and a function in the value distribution chain that stops at the dock-side (Holm 1995). Processors and exporters have similar organizations with whom sales-organizations negotiate, but if a settlement is not agreed to, the sales-organization can dictate the price. The layered structure, and the RFA and the sales-organizations which the law mandates, has also been kept intact by legislation. The Participation Act, which principles were introduced already in the early 1940s, ruled that only active fishers are allowed to own fishing vessels in Norway. This is by and large still the system, even if legal reforms have allowed investment by processors in the fishing fleet. This happened first in the trawler fleet in the $1950 \mathrm{~s}$, when an exception from the general rule was made where fish processors were given permission to own fishing vessels. In 2013, the Act was changed, and now non-active fishers, including processors, can now own up to
$49 \%$ of the vessel. This means that the majority interest continue to rest with the active fishers.

Fishers may be competitors in the fishing grounds, but they share a common interest in a high product price in transactions that are externalised (Williamson 1975). Collective action is therefore in their interest, and the fact that fishers have a similar background culturally and economically helps facilitate coordinated action. Although owned by fishers and managed in line with the classic cooperative principles of one memberone vote, the sales-organizations are not producer cooperatives that also engage in processing and marketing operations, thus making the transaction of raw fish at the dock side an internal affair within the same company. Still, some of these organizations have subsidiaries that are involved in other activities, such as fish processing. However, in recent years several of the sales-organizations have terminated such additional activities and concentrated solely on first-hand sales, which was always their core activity anyway.

The Second World War led to much of destruction, also in the fishing communities, and fishers were in need of landing facilities that had been destroyed. Initiatives to form producer 
cooperatives were taken with support from salesorganizations but few of them stayed operative for long (Otnes 1980; Revold 1980). The reasons for their failure are several and complex, but there is little doubt that the horizontal integration instituted by the NRA and the salesorganizations conflicted with the vertical integration of producer cooperatives. When fishers, by means of the NFA controlled the price in a way that secured their income, it did not make much sense to pursue a vertical integration for the same purpose, i.e. move into processing. One problem was that processing and export would require a kind of expertise that fishers did not have. The other problem was that such a move would mean that fishers would be at both sides of the table when prices were negotiated and fixed.

A high raw fish price, which was in the interest of the fishers, would not have been in the interest of the processing cooperative, as it would reduce its financial capacity. The fisher members found themselves in a double bind; whose interest should they serve; fishers as fishers or fishers as cooperative owners?

The layered system represented a "cleaner" model than a mixed horizontal and vertical system; it also did not challenge the already well-established and powerful buyer/export interests more than necessary, and who with the Salt-fish Act of 1932 already had formed their collective organization and granted legal protection (Holm 1995). Buyers/exporters were struggling to accept the role of taker. In the cod fisheries, exporters were collectively organized prior to the fishers - in contrast to the herring fisheries where vertical integration was more advanced (Hallenstvedt 1982).

The origin of the RFA and the fishers' sales-organizations is important. They came about as part of a broad-based grassroot labour movement combined with a proactive and enabling state government. It all started with the establishment of the Norwegian Fishers Association in 1926, followed by a series of initiatives aimed at strengthening the livelihoods of small-scale fishers and their communities (Fig. 1). The RFA and the sales-organizations emerged from below and within; they were not imposed upon fishers.

They were organizations of rather than for small-scale fishers with government playing a supportive role. The government no doubt saw the need for a less chaotic and ad-hoc organization as the fishing industry was after all one of Norway's most important exporter. What happened in the fishery was therefore of national significance. The state did not take a paternalistic position but rather listened to the voice of the fishers. The same labour movement that had brought forth the RFA also had a strong representation in the Parliament and from 1935 onwards actually was the base of the government.

After the Second World War, the government decided to financially support the fisheries. The system was formalised in 1964 when the Norwegian Fishers Association (NFA) and the
Ministry of Fisheries signed an agreement. It gave the NFA the right to represent the entire industry in negotiations with the government in an attempt to secure fishers an income comparable with other groups in society such as industrial workers. The government ended up giving subsidies mostly to enhance raw fish prices (Jentoft and Mikalsen 1987). When the market could not adequately provide for the fishers' economy, the state compensated.

In the beginning of the 1990s, however, due to a stronger market orientation, fisheries subsidies were questioned, more so because of the overcapacity problem within the fisheries. The European Union, with which Norway had an extended agreement, banned distortion of competition. As a result, government support was reduced and then removed (Hernes 1999; Finstad 2014).

For these historical reasons, the state even today enjoys overall legitimacy within the fishing population and the population at large (Skirbekk and Grimen 2012). The government is seen as part of the solution rather than the "enemy". When government is perceived as a constructive force, the governability of the fisheries sector is enhanced because it makes it possible to introduce rules and regulations that otherwise would have been difficult to implement and enforce. Thus, when the government introduced the new quota system in 1990, which effectively did away with the open access nature of small-scale fisheries, and launched strict measures to combat illegal and unreported fishing, it received reluctant support as opposed to fierce opposition from within the fishing population. The government could also mobilise the salesorganization for this purpose.

In contrast, when the government launched policies that led to a less proactive role for the state in fisheries, they met strong opposition. It is largely for this reason that the introduction of market-based fisheries management measures such as ITQs has been rather slow in Norway as compared to other Nordic countries such as Iceland and Denmark. It has simply not been politically possible to undertake full-scale privatization of common pool resources, at least not as yet (Hannesson 2013).

\section{Conclusion}

The fishing industry was always crucial for Norwegian economy and society, even for the way the country is settled. Today, seafood export, which includes farmed salmon, is second after oil. Norway is also one of the world's major exporters of fish. The home market consumes just a minimal volume (about $5 \%$ ) of fish caught and farmed. With fish exports being so important, transactions must be smooth and speedy, which the fishers' sales-organizations help to ensure.

Exporting fish is, however, less complicated than exporting institutions; institutions cannot be easily copied and implemented in other settings which Norway in fact tried to 
do in Kerala, India, in the 1950 s, but without much success. As Kurien (1985) argues in a study of the Kerala experience, there is an important difference between the organization of and for fishers. The former was the case as a result of the RFA and fishers' sales-organizations in Norway in the 1930s and beyond, whereas the latter was what Norway tried to do in Kerala in the 1950s, but with little success (Pharo 2000).

The social and political context within which new organizations such as fishers' sales-organizations emerge is always particular to time and place. Context differs but matters, even when counterfinality and second-order collective action problems occur. Context must therefore be taken into account when explaining why and how such organizations evolve and what shape they assume. General models, like counterfinality, give intuitive meaning but they do not tell the whole story. For that "thick description" (Geertz 1971) is needed.

How likely is it that the RFA and the sales-organizations that it legalises, would have been established in the current situation in Norwegian fisheries? The answer to this question is most probably 'highly unlikely'. But to abolish this law, and all the institutional structures that are derived from it, would nevertheless be a major intervention that would circumvent existing power-relations and change the way fisheries work in Norway. Its very existence carries a lot of power, which facilitates robustness against drastic political intervention.

This model of organization is incongruous to the neoliberal trend that is currently sweeping Norwegian fisheries and those of the rest of the Western world. Now, transactions are supposed to be left to the free market with government playing a less proactive role. In a competitive market, fishers do not see themselves as "comrades in arms", as they did to a greater extent in the 1930s. The RFA and the system of mandated fishers' sales-organizations have survived until this day, but their existence was never that solid and their future is uncertain (Grytås 2013b).

There are strong forces inside and outside Norway's fishing industry that want to take away the legal right from the salesorganizations to determine the minimum prices and the exclusive ownership that fishers have of the organizations. There are also those who disagree with the right sales-organizations have to regulate and direct vessels, whereas some of the salesorganizations have expressed that they are uncomfortable being asked to report on members who do not follow the quota regulations (Grytås 2013b).

The RFA and the sales-organizations are vulnerable to political regime shifts, particularly from the right. And they are also dependent on support from within the industry which might evaporate with changing circumstances. The combination of these factors may well be devastating.

As of now, symbolism has trumped real-politics. The RFA and the sales-organizations have been under pressure from the very beginning despite the almost unanimous support they have from the rank and file fisher members. Those in favour of abolishing the Act and sales-organizations have not presented a sufficiently convincing alternative system. The law has therefore changed little since 1938.

It stills enjoys support amongst most fishers, particularly small-scale fishers in the north. These fishers' salesorganizations are powerful institutions with a strong voice in Norwegian fisheries politics, and they are therefore not easily toppled. Whether the RFA and the sales-organizations are sustainable within an ITQ system is not at all clear even, if the principle of owner-operated fishing fleet will be maintained. One possibility is that the law would allow these organizations themselves to become quota owners. But as yet that is not on the cards.

Thus far, such vertical (upstream) integration is limited as the legal principle has been that only active fishers can own vessels. This rule, however, is now under threat from the same interests that are critical of the RFA. Sales-organizations were started to serve an independent, small-scale, owner-operated and open-access fishery with the aim to secure the livelihoods of economically and politically disadvantaged fishers who due to their high number counted politically. Their voice had to be reckoned with. Since 1990, the number of fishers in Norway has drastically reduced for several reasons, one of them being the quota system that has encouraged buy-outs.

Should that rule be abolished and the processors/buyers be allowed to became majority owners of fishing vessels, which a recent publish task force suggested, the RFA and the salesorganization would be undermined, as the RFA and the Participation Act are closely linked. The owner-operated fleet, which the current legislation maintains, creates the foundation of the layered system, and is a foundation of RFA and the sales-organizations. It maintains the relationship and the system of organised transaction between the independent seller (fisher) and buyer (processor). It would not make much sense with fishers and processors sitting on the same side of the negotiating table, as it would turn the system into a classical employer/employee relationship, and thus reverse the powerrelation to where it was before the RFA was introduced in the 1930s. The NFSO and other sales-organization therefore were in strong opposition to the recently published reform proposal, which did not survive the vote in the Parliament in 2015.

Although unique in context and institutional design, the RFA and the sales-organizations addressed a problem that small-scale fishers are still experiencing all over the world; one of poverty, marginalization and exploitation (Jentoft and Eide 2011). As the weakest party of the fisheries value distribution chain, small-scale fishers are typically price-takers in transactions with buyers. The NFA and the sales-organizations radically altered their predicament; they empowered fishers and moved them out of poverty. But the RFA was not only meant as a mechanism for income distribution. It was also introduced as incentive for the whole industry to work harder 
in export markets so as to bring in larger revenues for the entire industry and for the country as a whole whose economy relied on the fishery.

It could be argued that the relevance of these institutions is not restricted to Norway. Cooperative principles are valid regardless of circumstances and have been implemented in fisheries in many countries. Collective action is always essential to overcome problems within a fragmented industry. Organizations of fishers, backed by law and a proactive state, with a mission and a mandate to determine the basic conditions under which transactions take place, is applicable to other countries as well if the politics are conducive.

The poverty and marginalization that characterised Norwegian fishing in the 1920s and 1930s, and which the RFA and the sales-organizations were meant to eradicate is a reality in many parts of the world today. Such institutions, if they were to be introduced in other parts of the world would, require a break with the neoliberal ideology now inspiring fisheries reform all over the world. The future of Norwegian fishers' sales-organizations and their legal pillar involves an ideological and political battle. They are offspring of social democracy, grass-root power, and the ability of producers to see the need for working together for a common good. But their survival requires that they are able to move with the tide. They must be responsive to new challenges.

The RFA and the sales-organizations were initiated at a time when resources were not considered to be a limited resource. Rather, the situation was much the opposite. Fishers had more to sell at times than buyers could absorb. They still remained poor. Today, a key challenge is to make sure that the resource base is not overexploited, which means that fishing effort must be kept in check. Interestingly, the salesorganizations are well positioned to play an important role in such a governing system, by assuming necessary regulatory functions in a co-governance system. At the end of the day, the RFA and the sales-organizations depend on their ability to remain relevant as part of a governing system that has a social responsibility that extends beyond value chain transaction.

As a governance model, the Norwegian Raw Fish Act and the sales-organizations that the law facilitated, and the Participation Act that in addition are foundational for the fishing industry are not outdated. They were introduced to address the same problems that small-scale fisheries are facing in many instances around the world: poverty, vulnerability and marginalization. And who can say that if those institutions were dismantled in Norway, the problems that originally triggered these institutions would not resurface again? It is not for us to say how relevant the Norwegian model is for other countries. Those who would say no must also explain why not. What the Norwegian example does suggest, however, is that if there is will to foster institutions and organizations that make a difference to small-scale fishers, to the industry, and to the entire fisheries governance system, there is a way.
Acknowledgements The case study on which this paper was based was presented during the workshop on Strengthening organizations and collective action in fisheries - Towards the formulation of a capacity development program, held in Barbados on 4-6 November 2014. The workshop was organized by the Centre for Resource Management and Environmental Studies of The University of West Indies and financially supported by the Food and Agriculture Organization of the United Nations (FAO). This journal paper was discussed and reviewed at the write-shop on Strengthening collective action and organization in smallscale fisheries for poverty reduction organized by FAO on 16-18 November 2016 in Rome, Italy. Strengthening collective action and organizations is one of FAO's pillars to reducing rural poverty. The authors thank FAO for supporting the development of this work. The publication charges for this article have been funded by a grant from the publication fund of UiT The Arctic University of Norway. Daniela Kalikoski, Susana Siar, and Patrick McConney provided useful comments that helped to improve this paper.

Funding No particular funding was provided for the write-up of this paper.

Authors' contributions The two authors shared the writing of this paper. BPF contributed most to the historical section while SJ to the introduction, discussion and conclusion. Both authors read and approved the final manuscript.

Competing interests The authors declare they have no competing interests.

Publisher's Note Springer Nature remains neutral with regard to jurisdictional claims in published maps and institutional affiliations.

Open Access This article is distributed under the terms of the Creative Commons Attribution 4.0 International License (http:// creativecommons.org/licenses/by/4.0/), which permits unrestricted use, distribution, and reproduction in any medium, provided you give appropriate credit to the original author(s) and the source, provide a link to the Creative Commons license, and indicate if changes were made.

\section{References}

Berger, P.L., and T. Luckmann. 1967. The social construction of reality. A treatise in the sociology of knowledge. New York: Anchor Books.

Bull, E. 1979. Klassekamp og fellesskap 1920-1945. Vol. 13. Oslo: Cappelens Norgeshistorie.

Cappelen, Å.. and E. Røed Larsen. 2005. Hundre års ensomhet? Norge og Sverige 1905-2005. Økonomisk utvikling og verdiskaping, Statistics Norway, May 9.

Christensen, P. 1991. «En havens forpester, et kjempestinkdyr.» Om trålspørsmålet i Norge før den 2. verdenskrig. Historisk tidsskrift 4.

Christensen, P., and A. Hallenstvedt. 1990. På første hånd. Norges Råfisklag gjennom femti år. Tromsø: Norges Råfisklag.

Christensen, P., and A. Hallenstvedt. 2005. I kamp for havets verdier. Norges Fiskarlags historie. Trondheim: Norges Fiskarlag.

Davis, A., and S. Jentoft. 1989. Ambivalent Co-operators: Organizational Slack and Utilitarian Rationality in an Eastern Nova Scotian Fisheries Co-operative. Maritime Anthropological Studies (MAST) Vol. 2 (2) 1989, pp. 194-211. 
Finstad, B.-P. 2014. Markedstilpasning og globalisering. In N. Kolle (ed.): Norges fiskeri- og kysthistorie, Ch. 7, Vol. IV, pp. 215-249. Bergen: Fagbokforlaget.

Finstad, B.-P., and J. Lajus. 2012. The fisheries in Norwegian and Russian waters, 1850-2010. In D. J. Starkey, and I. Heidbrink (eds.): A history of the North Atlantic fisheries. From the 1850s to the early twenty-first century, Vol. 2, German maritime studies, no. 19, Bremen: Deutsches Schiffartsmuseum.

Finstad, B.-P. 1993. Fiskerinæringen i Finnmark under okkupasjonen. Unpublished MA-thesis. University of Tromsø.

Geertz, C. 1971. The interpretation of cultures. New York: Basic Books. Grytås, G. 2013a. Motmakt og samfunnsbygger. Med Norges Råfisklag og torsken gjennom 75 år. Trondheim: Akademika forlag.

Grytås, G. 2013b. Råfisklova - tid for tale ved grava? In Jentoft, S., J-I. Nergård and K. A. Røvik (eds.): Hvor går Nord-Norge? Stamsund: Orkana Akademisk.

Hallenstvedt, A. 1982. Med lov og organisasjon. Organisering av interesser og markeder i norsk fiskerincering. Tromsø: Universitetsforlaget.

Hallenstvedt, A., and B. Dynna. 1976. Fra skårunge til høvedsmann. Med Norges Fiskarlag gjennom 50 år. Trondheim: Norges Fiskarlag.

Hannesson, R. 2013. Norway's experience with ITQs. Marine Policy 37: 264-269.

Heckathorn, D.D. 1989. Collective action and the second-order free-rider problem. Rationality and Society 1 (1): 78-100.

Hernes, H.-K. 1999. Forhandlingsmakt eller argumentasjonsbyrde? En analyse av Hovedavtalen for fiskerinæringen og avviklingen av fiskeristøtten. Unpublished doctoral dissertation, Universitetet $\mathrm{i}$ Tromsø.

Hersoug, B. 2006. Closing the commons. Norwegian fisheries from open access to private property. Delft: Eburon Publishing.

Hersoug, B., B.-P. Finstad, and P. Christensen. 2015. The system of Norwegian fish sales unions - An anachronism or a successful adaptation to modern fisheries? Acta Borealia 32(2):190-204.

Holm, P. 1995. The dynamics of institutionalization: Transformation process in Norwegian fisheries. Administrative Science Quarterly 40 (3): $398-422$.

Hovland, E. 2014. Kontrastfylt næringsutvikling. In N. Kolle (ed.): Norges fiskeri- og kysthistorie, Ch. 10, Vol. III, pp. 287-294. Bergen: Fagbokforlaget.

Hovland, E., A. Haaland, and Å. Svihus. 2014. Silde-Norge og TorskeNorge. In N. Kolle (ed.): Norges fiskeri- og kysthistorie, Ch. 12, Vol. III, pp. 335-355. Bergen: Fagbokforlaget.

Jentoft, S., and A. Eide. 2011. Poverty mosaics. In Realities and Prospects in Small-Scale Fisheries. Dordrecht: Springer Science.

Jentoft, S., and T.I. Kristoffersen. 1989. Fishermen's co-management: The case of the Lofoten fishery. Hum Organ 48(4):355-365.

Jentoft, S., and K.H. Mikalsen. 1987. Government subsidies in Norwegian fisheries: Regional development or political favoritism? Mar Policy 11(3):217-228.
Johansen, K. E. 2014. Eit tidsskilje - motoriseringa. In N. Kolle (ed.): Norges fiskeri- og kysthistorie, Ch. 3, Vol. III, pp. 75-103. Bergen: Fagbokforlaget.

Kurien, J. 1985. Technical assistance projects and socio-economic change. Norwegian intervention in Kerala's fisheries development. Economic and Political Weekly, Vol. XX, Nos. 25 and 26. pp. 70-88.

March, J.G. 1962. The business firm as a political coalition. J Politics 24 (04): 662-678.

McCay, B., and S. Jentoft. 1998. Market or community failure? Critical perspective on common property research. Hum Organ 57 (1): 21 29.

Nielsen, J.P. (ed.) 2014. Russland kommer ncermere. Norge og Russland 1814-1917. Oslo: Pax forlag.

Niemi, E. (ed.) 1992. Pomor: Nord-Norge og Nord-Russland gjennom tusen år. Oslo: Gyldendal forlag.

NOS. 1901. Norges Officielle Statistik. Fjerde Racke Nr. 21. Tabeller vedkommende Norges Fiskerier i Aaret 1900. Kristiania: Norges Fiskerisstyrelse.

Olson, M. 1971. The logic of collective action. Public goods and the theory of groups. Cambridge: Harvard University Press.

Ostrom, E. 1990. Governing the commons: The evolution of institutions for collective action. Cambridge: Cambridge University Press.

Ot.prp. nr. 20 (2007-2008). Om lov om forvaltning av viltlevande marine ressursar.

Otnes, P. 1980. Fiskarsamvirket i Finnmark. Arbeidsnotat nr. 153. Institutt for sosiologi, Universitetet i Oslo.

Pharo, H. 2000. Fisheries development in India and Norwegian foreign aid: The case of the Kerala project. Mimeo. Oslo: University of Oslo.

Revold, J. 1980. Fiskarsamvirke. Modernisering og fellesorganisering. Unpublished MA thesis. Institutt for fiskerifag, Universitetet $\mathrm{i}$ Tromsø.

RFA 2013. Lov om førstehandsomsetning av viltlevande marine ressursar.

Rønning Balsvik, R., and Drake, M. 1994. Menneskene i Nord-Norge. Fra istid til nåtid - fra vogge til grav. Pp. 82-145. In E.-A. Drivenes, M.A. Hauan and H.A. Wold (eds.): Nordnorsk kulturhistorie: Det gjenstridige landet. Gyldendal Norsk Forlag: Oslo.

Sartre, J.-P. 2006. Critique of Dialectical Reason. Vol. 2. London: Verso.

Skirbekk, H., and H. Grimen. 2012. Tillit i Norge. Oslo: Res Publica.

Solhaug, T. 1983. De norske fiskeriers historie 1815-1880. Universitetsforlaget.

Vayda, A.P. 1996. Methods and explanations in the study of human actions and their environmental effects. CIFOR WWF. Special publications. Jakarta: Center for international forestry research and world wide Fund for Nature.

Wadel, C. 1980. Lokalsamfunn, hushold og bedrift. Noen aktuelle næringspolitiske koordineringsproblemer i kyst-Norge. In I.L. Høst, and C. Wadel (eds.): Fiske og lokalsamfunn. Tromsø: Universitetsforlaget.

Williamson, O.E. 1975. Markets and hierarchies. Analysis and antitrust implications. New York: The Free Press. 